\section{International Scientific Journal Theoretical \& Applied Science}

\author{
p-ISSN: 2308-4944 (print) e-ISSN: 2409-0085 (online) \\ Year: 2015 Issue: 07 Volume: 27
}

Published: $30.07 .2015 \quad \underline{\text { http://T-Science.org }}$
Dorota Kozlowska

Ph., D., Assistant professor Nicolaus Copernicus in Torun, Faculty of Earth

Sciences, Poland

kozlowska_dorotka@wp.pl

Wojciech Ryszkowski

Associate Professor,

the Józef Piłsudski Academy of Physical Education

in Warsaw, Poland

SECTION 34. Tourism.

\title{
HEATHY ALTERNATIVE OFFERINGS FOR TOURISTS SITES IN NORTH-EASTERN POLAND
}

\begin{abstract}
Health education should provide the overall development of fitness and efficiency; health improvement; immunity; inurement; ageing prevention; full physical strength, mental recovery; satisfaction of health needs; and respect for your health and life. The health function is connected with reducing the stress and fatigue which results from biochemical and physiological changes experienced in day to day life.

The study aimed at evaluating the level of health function based on the opinions of guests who were staying in chosen tourist sites in north-eastern Poland. It was assumed that the highest levels of health function could be found at either a Jacwisko- Prussian settlement, on a Masurian farm or at an ecological farm during a safari event. The survey was conducted among 22 guests and its results showed that the Masurian Farm had the best conditions to realize the health function (health function- $54.93 \%$ and holiday resort function- 58.79\%). The farm serves natural food such as homemade bread, butter and other products. The presence of typical farm animals such as horses, cattle, sheep, goats, fur-bearing animals and poultry helped with mental and physical recovery. The next two tourist attractions also rated highly with the following results: the agro tourist farm called Silaine (with health function- 51.64\% and holiday resort function- 52.21\%) and an estate Gize Marczak (with health function- $44.56 \%$ and holiday resort function- $48.06 \%$ ). These results show that the assumptions formed in the article were not completely confirmed.
\end{abstract}

Key words: health function, holiday resort function, tourist site.

Language: Russian

Citation: Kozlowska D, Ryszkowski W (2015) HEATHY ALTERNATIVE OFFERINGS FOR TOURISTS SITES IN NORTH-EASTERN POLAND. ISJ Theoretical \& Applied Science 07 (27): 151-162.

Soi: http://s-o-i.org/1.1/TAS-07-27-27 Doi: crossef http://dx.doi.org/10.15863/TAS.2015.07.27.27

\section{ОЗДОРОВИТЕЛЬНЫЕ ФУНКЦИИ ПРЕДЛАГАЕМЫЕ В ИЗБРАННЫХ ТУРИСТИЧЕСКИХ ОБЪЕКТАХ СЕВЕРО - ВОСТОЧНОЙ ПОЛЬШИ}

Аннотация: Оздоровительное воспитание и отдых должны обеспечивать общее развитие чёткости и работоспособности, укрепление здоровья, устойчивость, закалку, противодействие проиессам старения, регенерацию физических и психических сил, удовлетворение оздоровительных необходимостей, уважение жизни и здоровья. Функиия эта связана с отдыхом, ликвидацией утомления лежащего в основе биохимических, физиологических и других изменений лежащих в сфере субъективных испытаний человека. Целью исследований была оценка ступени выполнения оздоровительной функции туристики в мнении гостей находящихся в избранных объектах северо-восточной Польши. Заложили, же оздоровительнье функиии в самой большой ступени могут быть реализованы в Посёлке Яцьвеско - Прусском, Мазурской Ферме и в экологическом хозяйстве во времени мероприятия „Сафари”. Исследования проведено на основании анкетирования среди 22 гостей туристических объектов. Результаты исследований показали, же функции оздоровительные и для отдыха наиболее выгодно можно реализовать в Мазурской Ферме (оздоровительная функиия 54,93\%; для отдыха 58,79\%). В хозяйстве сервировали здоровую пищу: домашняя еда вместе с хлебом из собственной выпечки, домашним маслом и другими продуктами. Психо физический отдых помогает пребывание с типичными видами домашних зверей, напр. с конями, со стадом выращенного скота, овцами, козами, меховыми зверями, с выращенной птицей. Очередное место заняли: агротуристическое хозяйство Силяине (оздоровительная функиия 51,64\%; для отдыха 52,21\%) и 
Имущество Гиже Марчак (оздоровительная функция 44,56\%; для отдыха 48,06\%). Такие результаты указывают на констатацию, что предположения не подтвердились полностью.

Ключевые слова: оздоровительная функция, функциия для отдыха, туристический объект.

\section{Введение}

Туристика принадлежит к рекреационно познавательным областям. Благодаря туристике каждый выполняет разнородные цели и туристическо - рекреационные функции. Туристика удовлетворяет физические, психические и интеллектуальные нужды. Возделывание произвольной формы туристики доставляет много впечатлений вытекающих из окружения и мотивировки к физической активности. "Возделывание туристики поднимает чёткость, жизненную расторопность, составляет „калитку” в общественные контакты, в участие в натуральных жизненных ситуациях, делает возможным проверку себя в сфере умения практического действия и общественного сохранения в среде" [2, с. 223]. Всё больше туристических и агротуристических объектов вводит в предложение возможность укрепления здоровья, отдыха и образования.

В туристических теориях обмениваются следующие классические функции, в которых засчитываем 9 главных функций с разделением трёх из них на „подфункции” (рис. 1) [1; 9; 10]. В соответствии с этими функциями авторы опубликовали исследования связанные с возможностью выполнения отдельных функций в объектах туристики в северо-восточной Польше [4-8].

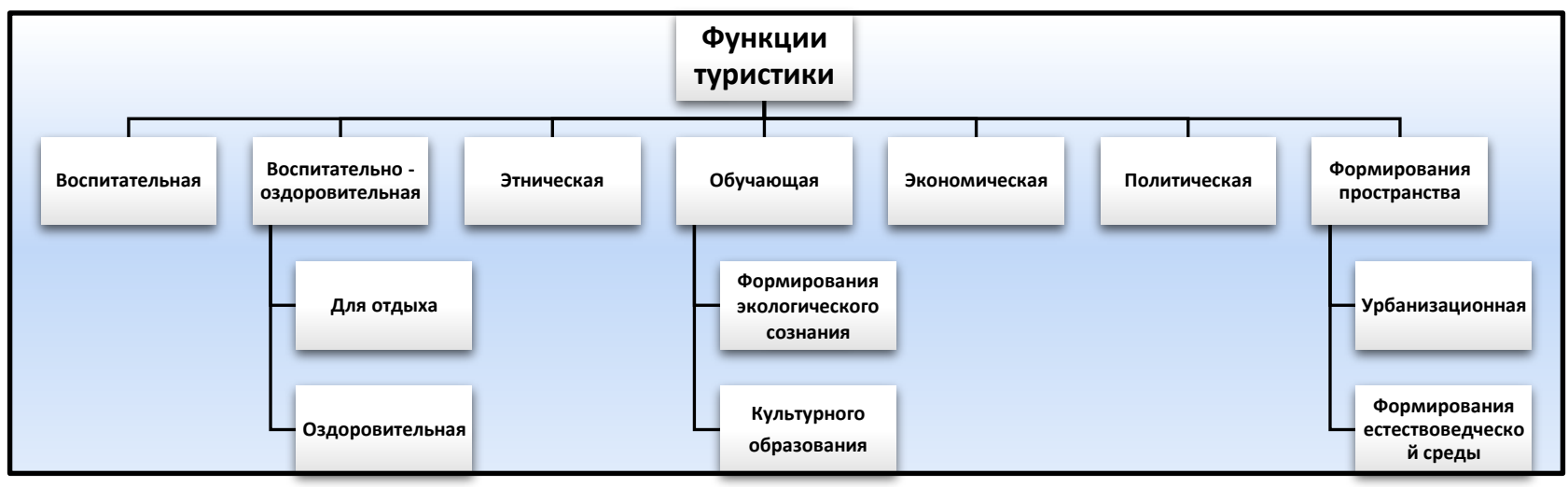

Рисунок 1 - Функции туристики.

Источник: [10] (za Panasiuk 2006, p. 34)

Оздоровительное воспитание должно обеспечивать общее развитие, развитие чёткости и работоспособности, укрепление здоровья, устойчивость, закаление, противодействие процессам старения, регенерацию физических и психических сил, удовлетворение оздоровительных нужд, уважение жизни и здоровья. Функция эта связана с функцией для отдыха которая относится к ликвидации утомления лежащего в основе биохимических, физиологических и других изменений лежащих в сфере субъективных впечатлений человека. Оздоровительная функция ориентированна на оздоровительные достоинства туристики. Показывает на необходимость отрыва от загрязненной среды и перехода в неиспорченную среду. Она относится к усилию. Возможно она выполняется напр. во время путешествий в полезном климате (пребывание на море, водохранилищами, в лесах, горах). Она часто объединяется с квалифицированной туристикой, как школой закалки организма и закаления на препятствиях судьбы. B процессе оздоровительного воспитания она связаная с общим развитием, улучшением чёткости и работоспособности, укреплением здоровья, устойчивостью, закалкой организма, противодействием процессам старения, регенерацией физических и психических сил, удовлетворением оздоровительных необходимостей, уважением жизни и здоровья [3; 9, с. 48-84].

Главные принципы отдыха должны отодвигать утомление после ежедневной работы, физическим и умственным усилиям и предпочитает активный отдых. Программа круглогодового отдыха должна учитывать отбор занятий приспособленных к климатическим изменениям в разные времена года [9, с. 48-84].

\section{Методология исследований}

Цель и предпосылки исследований. Целью исследований была оценка ступени выполнения оздоровительной функции туристики и функции отдыха по мнению потребителей (гостей) находящихся в избранных объектах северо - восточной Польши. Заложены, же эти 
функции в самой большой степени реализуются в Яцьвеско - Прусском Посёлке, Мазурской Ферме и в экологическом хозяйстве во время мероприятия Сафари.

Методы и исследовательские техники. В исследованиях применен метод диагностического зондирования, наблюдение на местности и анкетирование. Исследования проведено на основании анкетирования основанной на выполнении функции туристики. Ввиду обширности исследований в этой обработке представлена только небольшая часть результатов исследований.

\section{Характеристика}

исследуемых. Исследования проведено среди 22 гостей туристических объектов. Гости в большинстве $(86,36 \%)$ были студентами (II, III и IV год обучения) и участниками отъездов практических занятий (апрель-июнь 2012) реализованных в пределах предметов на направлениях: Туристика и отдых; Сельское хозяйство специальность Агротуризм. Остальные респонденты $(13,64 \%)$ были работниками туристической отрасли (бюро, учебные заведения) и участниками учебных визитов (в годах 2010-2012) в пределах проектов: Сувальщизна Страна как Сказка (CA) и Страна Охотников Приключений (ЭГО). Женщины составляли $63,64 \%$ исследуемых, мужчины $36,36 \%$ совокупности. Больше чем половина исследуемых $(63,64 \%)$ была до 25 лет, остальные $(36,36 \%)$ между 25 и 50 годами жизни. Почти все исследуемые $(90,91 \%)$ проживали в подляской области, немногочисленные $(9,09 \%)$ варминско мазурской. Анкетирование в целом проведено в интернетной форме. Заданием исследуемых была оценка выполнения оздоровительной и воспитательной функции в масштабе 0-10 в отдельных объектах. Исследуемые оценивали только эти объекты которые узнали в туристической практике, поэтому результаты исследований тоже представлены в форме \% (некоторые объекты оценивались среди 22 гостей, некоторые среди 16 гостей).

\section{Результаты собственных исследований}

\section{Оздоровительная функция}

Исследования показали, что в мнении свыше половины гостей туристических объектов наиболее полезно можно выполнять оздоровительную функцию в агротуристическом Хозяйстве Ферма Мазурская $(54,93 \%)$ и в агротуристическом Хозяйстве - Центр Отдыха и Развлечения Силяине $(51,64 \%)$. В оценке свыше $40 \%$ респондентов функция здоровья реализована преимущественно в Имуществе Гиже Марчак (44,56\%); Липняке - Центре Поддержки (44,29\%); в Пчеловодческом Скансене, Музее Железной Дороги и Мастерской Скульптуры (45,53\%); Экологическом хозяйстве во времени Пробега Сафари (42,38\%); на Красивой Горе (42,28\%); на дидактической дороге в окружении пирамиды в Рапа $(41,28 \%)$ и в Усадьбе Милоша (40,63\%).

В анкетировании немного свыше $1 / 3$ респондентов функция здоровья эффективно выполняется в Святилище в Студеничной $(38,58 \%) ;$ в Яцьвеско - Прусском Посёлке $(37,62 \%)$; на Дороге Молочной Коровы во время кулинарных мастерских "Гижанки" (35,80\%); в Саду Сказок "Сова" (35,25\%); на пространстве Августовского Канала - шлюза Панево (35,25\%); на Тисовой Горе $(35,05 \%)$ и на пространстве скал Баханово, Рутка (35,0\%).

В анкетировании свыше половины гостей исследуемых, похоже как и в случае оздоровительной функции, функция отдыха эффективно выполняется на Мазурской Ферме $(58,79 \%)$ и в Силяине $(52,41 \%)$. Свыше $40 \%$ гостей побывающих в туристических объектах оценила предложение Имущества Гиже Марчак (48,06\%), Пчеловодческого Скансена, Музея Железной дороги, Мастерской Скульптуры (46,93\%); Предложение Центра Поддержки Липняк $(42,0$ \%); Предложение объекта рекреационно - спортивно Красивая Гора (40,72\%) и мероприятие Пробег Сафари (40,57\%) способствуют эффективному отдыху. Предложения остальных объектов оценены на немного низшем уровне выполнения функции отдыха. Предложение Тисовой Горы $(29,64 \%)$ в самой маленькой сфере реализует выполнение функции отдыха (рис. 2). 


\begin{tabular}{|c|c|c|c|c|c|c|}
\hline Impact Factor: & $\begin{array}{l}\text { ISRA (India) } \\
\text { ISI (Dubai, UAE } \\
\text { GIF (Australia) } \\
\text { JIF }\end{array}$ & $\begin{array}{r}=1.344 \\
=\mathbf{0 . 8 2 9} \\
=\mathbf{0 . 3 5 6} \\
=\mathbf{1 . 5 0 0}\end{array}$ & $\begin{array}{l}\text { SIS (USA) } \\
\text { PИHЦ (Russia) } \\
\text { ESJI (KZ) } \\
\text { SJIF (Morocco) }\end{array}$ & $\begin{array}{l}=0.912 \\
=0.179 \\
=1.042 \\
=2.031\end{array}$ & ICV (Poland) & $=6.630$ \\
\hline
\end{tabular}

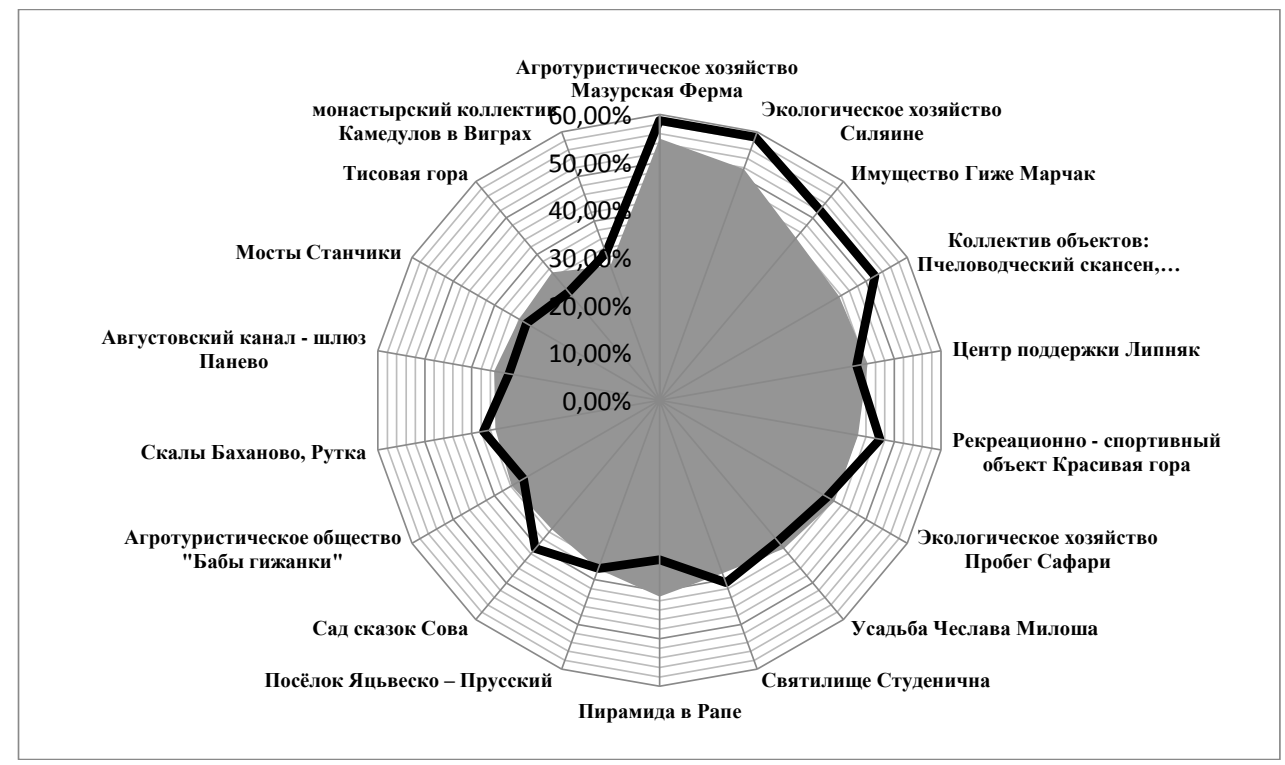

Рисунок 2 - Сравнение уровня выполнения функции оздоровительно - курортных в туристических

Источник: собственная обработка объектах северно - восточной Польши.

Легенда: серый цвет оздоровительная функиия; чёрный цвет: функция для отдыха

\begin{abstract}
Общие результаты исследований и описание туристических мест

В оценке исследуемых самое высокое место заняла Мазурская Ферма. В мнении свыше половины исследуемых (54,93\%) на ферме можно отдохнуть и укрепить здоровье. На ферме выступают все типичные виды хозяйственных зверей, напр. 6 коней, стадо выращенного скота, овцы, козы, меховые звери, звери выращиваемые методом свободного размножения. Оздоровительную функцию и функции отдыха можно выполнять через подражание: возможность лепки и выпечки хлеба и игрушек из теста, ознакомления и подкармливания зверей и т.п. Был это единственный агротуристический
\end{abstract}

объект среди исследуемых в котором были все виды зверей, птиц и меховых зверей. В хозяйстве сервировали здоровую пищу - домашнюю еду вместе с хлебом собственной выпечки, домашним маслом и другими продуктами. Достоинство фермы - функционирование хозяйства в поддержке семейной модели. Основным козырем предложение очень большого количества самых дешёвых ночлежных мест под лозунгом „дешёвый сон на сеяние”. Хозяйство теперь проходит модернизацию. Сон на сене заменен на небольшие апартаменты. Предложение сна на сене по-прежнему будет функционировать в части этого самого здания (рис. 3 ).

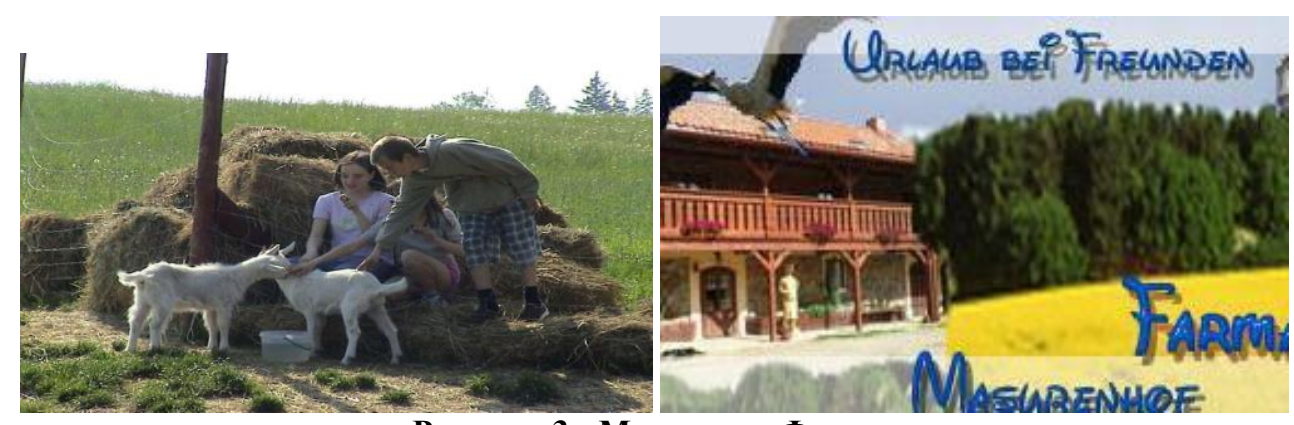

Рисунок 3 - Мазурская Ферма.

Источник: www.mazury.com

Второе место (51,93\%) в сфере выполнения оздоровительной и функции отдыха заняло
Агротуристическое хозяйство “Силяине”. Объект локализованный на берегу озера, предлагает 
возможность участия в практическом разведении коней. Хозяйство предлагает: горячую бочку и сауну на озере. Большие группы могут ночевать в палатах военного типа. Существует также небольшая подвесная канатная дорога. Ночлежную базу составляют: большой старинный семейный дом. В погребах дома функционирует кухня, в которой работают кулинарные мастерские со здоровой пищей. Владельцы готовят направленные на здоровую пищу и диеты для похудения. Владельцы также ведут производство сыров с содержанием разных трав. Большая открытая местность позволяет отдых. На пространстве хозяйства находится скансен в котором владелец собрал коллекцию инструментов и сельскохозяйственных устройств использованных в XX веке в сельском хозяйстве. На озере существует тоже большая сцена приспособлена к сезонным концертам (рис. 4).
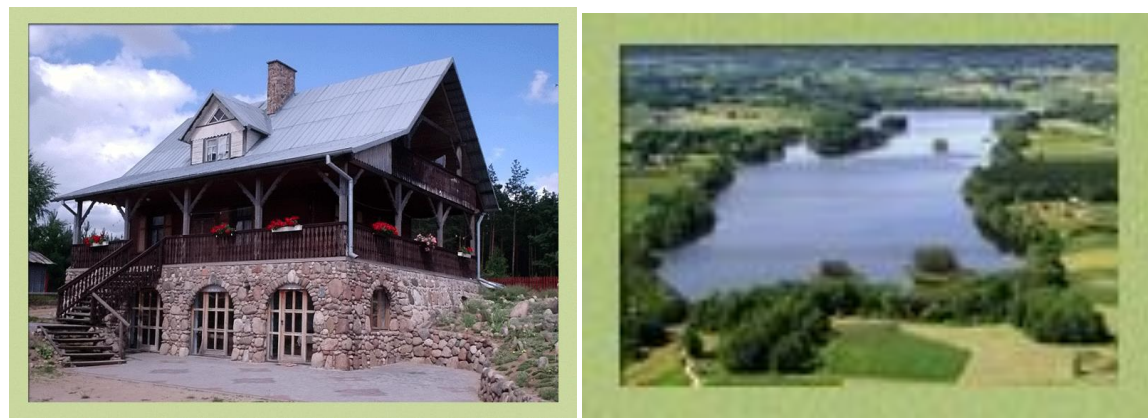

Рисунок 4 - Экологическое хозяйство Силяине.

Источник:www.silaine.mnt.pl

На третьем месте разместилось Агротуристическое (экологическое) хозяйство Гиже - Марчак (46,31 \%), хозяйство так называемой „самой высокой полки”, занимающее 21 гектар, гостиница с повышенными стандартами, озеро, лыжная трасса, летние домики для ребят и залы для занятий в рамках услуг ,зелёной школы”. На местах находятся доступные плантации малин. Перед гостиницей и рестораном находятся: рыбное озеро и прибрежная сауна. Гостьми этого хозяйства был президент РП - Л. Качыньски, гости посольств и центральных учреждений. В объекте часто проводят съёмочные сессии программы польского телевидения (рис.5).

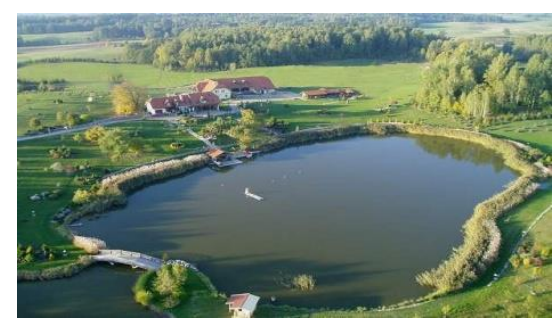

Источник: www.marczaknoclegionline.net

Рисунок 5 - Имущество Гиже Марчак.

Место четвёртое занял Коллектив объектов: Пчеловодческий скансен, Музей железной дороги и Мастерская Скульптуры (45,23 \%). В скансене можно увидеть уникальных бортей использованных в разных областях Польши. Уникальные ульи изваяли в древесине. Существуют тоже борти созданные природой. В предложении музея можно увидеть исторический локомотив, железнодорожный подвижной состав, прежние карты и устройства применяемые в железнодорожном транспорте. В мастерской скульптуры можно познакомиться с работой любителей и профессионалистов скульптуры. Приготовленные в древесине изделия относятся к сакральным и светским видам (рис. 6). 
Источник: собственное

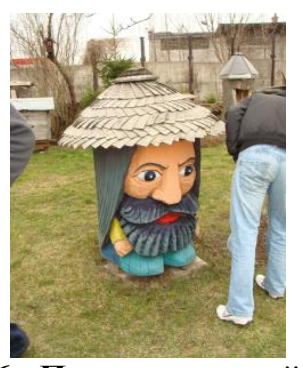

Рисунок 6 - Пчеловодческий скансен.

Центр поддержки Липняк находится на пятом месте $(43,15 \%)$. В центре оздоровления людей после психических кризисов. Это особенный род возвращения в ежедневную жизнь и нормальное функционирование в здоровом обществе. Центр на пространстве заповедника Вятролужа, на реке горного типа. Благоустройство местности допускает отдых на свежем воздухе и пленарные встречи у гриля. Центр особенно направлен на приём взрослых людей с аутизмом. В пределах терапии организуются мастерские в сфере ежедневной жизни, рукоделия из лозы, художественных изделий и керамики. Центр принимает также группы здоровых людей (рис. 7).

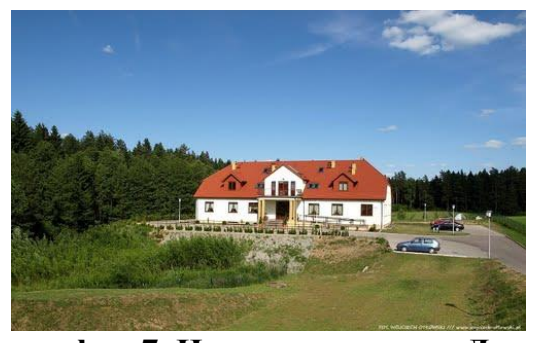

Фотография 7. Центр поддержки Липняк.

Источник: www.panoramio.com

Место шестое занял рекреационно спортивный объект Красивая Гора с результатом $41,50 \%$. Владельцы владеют двумя ресторанами с гостиницей и рекреационной частью (канатный парк и парк игр для детей), лыжной трассой вместе с оборотной пейзажной башней и рестораном. Объект имеет современный дизайн соединённый с элементами декора связанного с охотничьим в лесах Пущи Роминцкей (рис. 8).

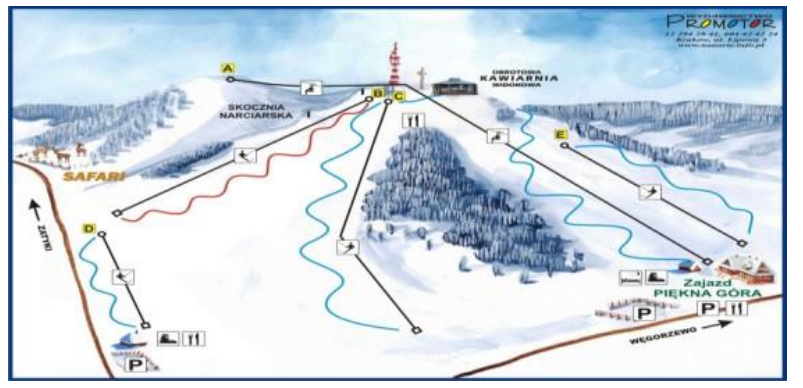

Рисунок 8 - Рекреационно - спортивный объект Красивая гора.

Источник: www.zajazd-rudziewicz.pl

Очередное место занял Пробег „Сафари” $(41,48 \%)$. Мероприятие организуется этими самими владельцами, которые владеют объектом Красивая Гора. Экологическое специализированное хозяйство „Сафари” основано на поверхности 350 гектарах: имеет около 20 озер и водных петель, огороженное высокими лесно-дорожными сетками. В хозяйстве пасутся на свободе очень большие стада: лани, косули и оленьи, марали, и тарпаны, кони Пшевальского, дикие овцы аруи, муфлоны, яки, страусы, павлины, кабаны и сьвинёдики. В вольерах декоративная птица. Диких зверей, можно смотреть и подкармливать с тракторных 


\begin{tabular}{|c|c|c|c|c|c|}
\hline Impact Factor: & $\begin{array}{l}\text { ISRA (India) } \\
\text { ISI (Dubai, UAE } \\
\text { GIF (Australia) } \\
\text { JIF }\end{array}$ & $\begin{array}{l}=1.344 \\
=0.829 \\
=0.356 \\
=1.500\end{array}$ & $\begin{array}{l}\text { SIS (USA) = } \\
\text { PИHЦ (Russia) = } \\
\text { ESJI (KZ) = } \\
\text { SJIF (Morocco) }\end{array}$ & $\begin{array}{l}=0.912 \\
=0.179 \\
=1.042 \\
=2.031\end{array}$ & ICV (Poland) \\
\hline
\end{tabular}

прицепов. Хозяйство несет существенную воспитательную функции (рис.9). курортную, оздоровительную, познавательную и
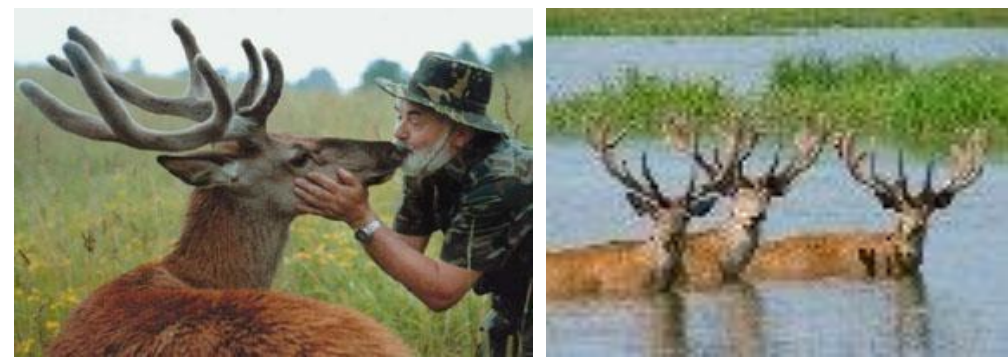

Рисунок 9 - Экологическое хозяйство Пробег “Сафари”.

Источник: www.zajazd-rudziewicz.pl

Усадьба Чеслава Милоша (39,06\%) в Красногруде исполняет функции: для отдыха и оздоровительную в сфере „выздоровления души”. Восстановленный объект в пределах деятельности Центра Приграничная зона, Международного Центра Диалога оказывается местом отдыха и образования в сфере широкого искусства. На местности объекта приготовили воспитательную трассу на свежем воздухе, а внутренность объекта предлагает задумчивость над творчеством и существованием Лауреата Нобеля (рис. 10).

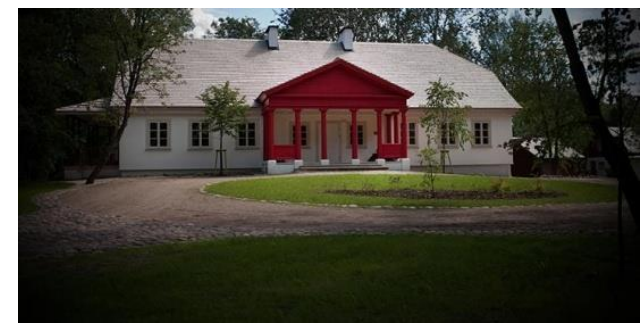

Источник: www.pogranicze.sejny.pl

Рисунок 10 - Усадьба Чеслава Милоша.

Место девятое заняло святилище в Студеничной $(38,58 \%)$. Известное с древних веков место предлагает тишину и покой среди лесов на озере Студеничне. На территории ключевая оздоровительная вода - колодец с водой, памятник Римскому Папу - сувенир после визита в 90-х годах, функционируют часовни на острове, часовня на воздухе и деревянный костёл (рис. 11).

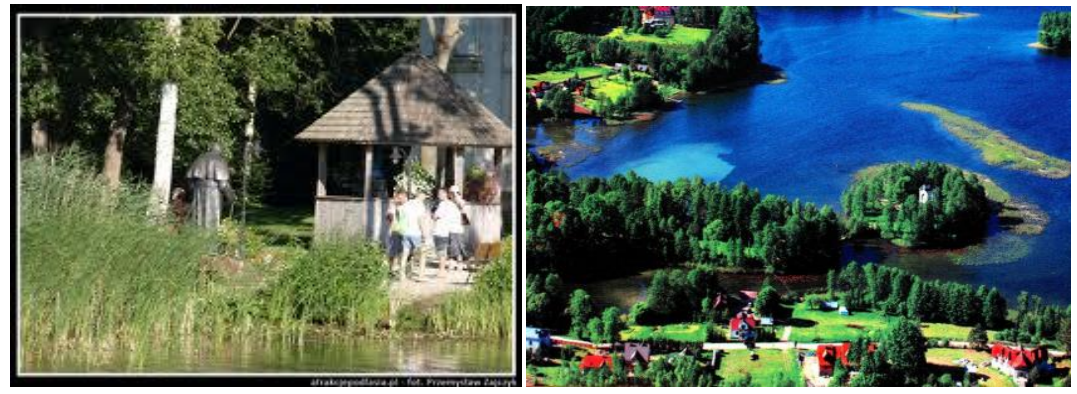

Рисунок 11 - Святилище Студенична.

Источник: www.atrakcjepodlasia.pl, www.za-mostkiem.pl

Гробница семьи Фарэнхэит находится в местности Рапа недалеко Мазурских Бань, рядом с границей России (Калининградская область). Владельцы поместья принадлежали к образованным людям. Много путешествовали по
Европе и вводили много нововведений в своём домовладении. Притягивала их магия вечного "жизни после жизни". В начале XIX в., на расстоянии около 5 км от дворца воздвигли пирамиду. В гробнице в 1811 впервые была 
похоронена 3 -летняя дочка Фарэнхэита возможно с мыслью поддержания её бессмертия. Пирамида в Рапе отвечает мерам египетских пирамид: высота 15,9 м, квадратная основа 10,4 м х 10,4 м, три вентиляционные отверствия, гробы уложенные на плоской почве. В пирамиду ведёт дидактическая дорога.

В Рапе пересекаются три линии сильного геомагнитного излучения соединяющие места силы. Одна из них идёт с Каунаса через Рапу и далее через Волчий Шанец доKarlsruhe. Это одно из больших мест силы в Европе. Излучение энергии в мазурской пирамиде по Лешеку Матели возводится около 23 тыс. личностей в масштабе Бовиса. Излучение здорового человека 6,5 тыс. личностей, а места о напряжении 18 тыс. личностей, считаются местами силы. Комары и мухи будто бы обходят пирамиду [on line www.mazury.info.com]. Объект занял десятое место по результатам анкетирования 38,22 \% (рис. 12).

Источник: собственное

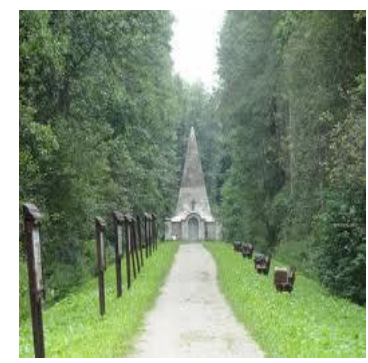

Рисунок 12 - Пирамида в Рапе.

На одиннадцатом месте Посёлок Яцьвеско Прусский $\quad(37,40 \%)$. В этом хозяйстве реконструкции средневекового поселения с палисадным забором, обманываемым мостом и двумя башнями и ночлежными местами. В хозяйстве находилось 5 коней под седло. Развлечение этого хозяйства каменный круг и включение мистических обрядов и рассказов легенды границы жмудзкего. Примером использования верований и легенд является каменный отождествляемый круг с магической силой. Достоин подчёркивания факт что свою туристическую привлекательность хозяйство построило в девственной местности (рис. 13).

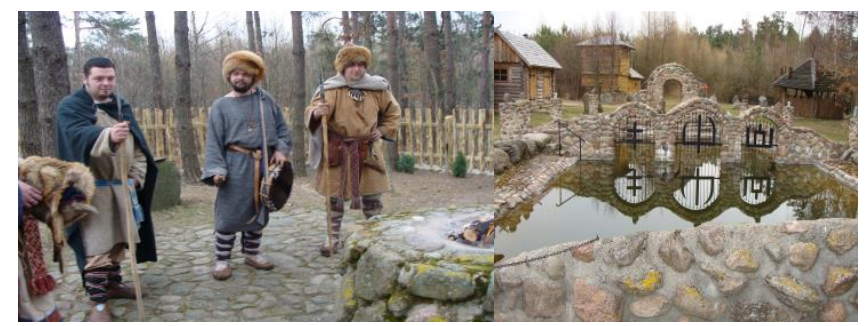

Источник: собственное

Рисунок 13 - Посёлок Яцьвеско - Прусский.

На двенадцатом месте (36,38\%) расположилось хозяйство площадью около 2 гектаров показывающее разный от традиционно понимаемого агротуризма продукт - Сад Сказок. Продукт объекта касается страны сказок. Сказочные персоны в натуральных величинах, расположенные в собственно преданной декорации дополняет местная загадка с наградами для самых хороших. Это хозяйство показывает на неиспользованные до сих пор тематические формы, или возможность соединения множества специализированных форм в своеобразные пакеты направленные на самих молодых потребителей, для которых культовый агротуризм не целиком понятный (рис.14). 


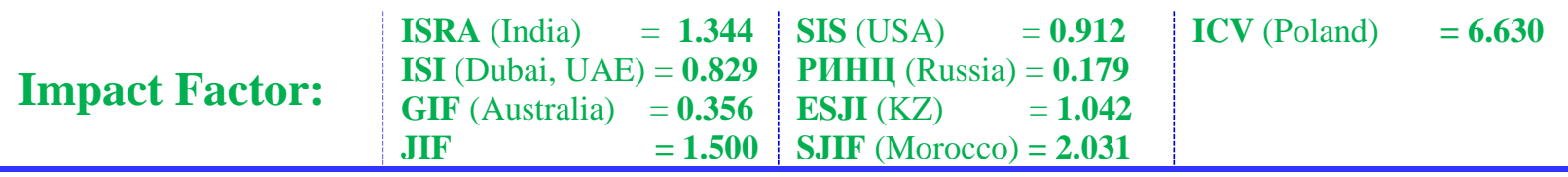

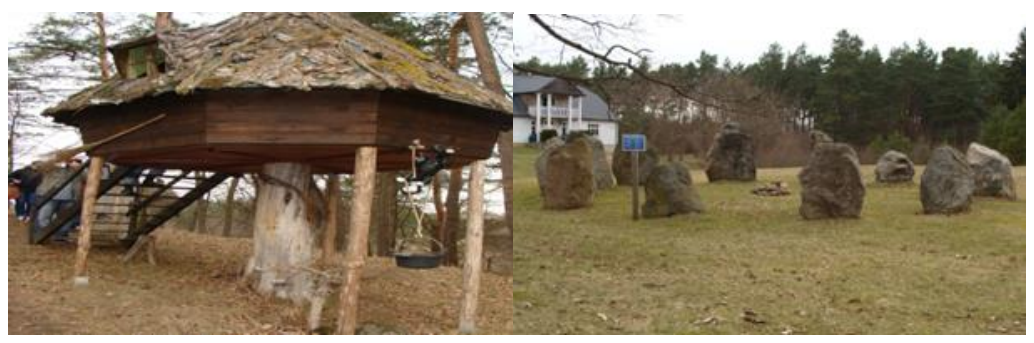

Рисунок 14 - Сад сказок Сова.

Источник: собственное

Тринадцатое место $(34,35 \%)$ заняли мастерские организованные Обществом Гижовских Баб - Дорога Молочной Коровы. Во время мастерских можно релаксироваться на природе, выучить приготовление вкусных сырных пирогов, и других изделий из молока (рис. 15).

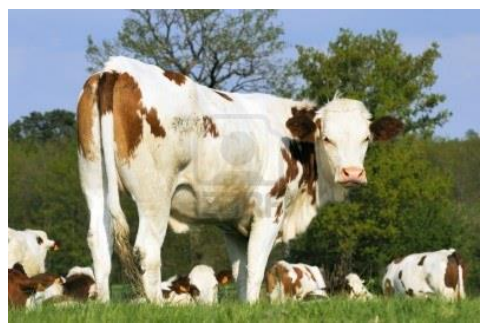

Рисунок 15 - Агротуристическое общество "Бабы гижанки".

Источник: www.pl.123rf.com

Скалы положенные в заповеднике Сувальского Пейзажного Парка - остаток после последнего ледника. Небольшой фрагмент лугов охраняется. Выступают здесь скалы достающие 8 метров. Можно перейти трассой к реке в окружении камней. Скалы заняли место четырнадцатое в сфере здоровья и отдыха с результатом $34,21 \%$ (рис.16).

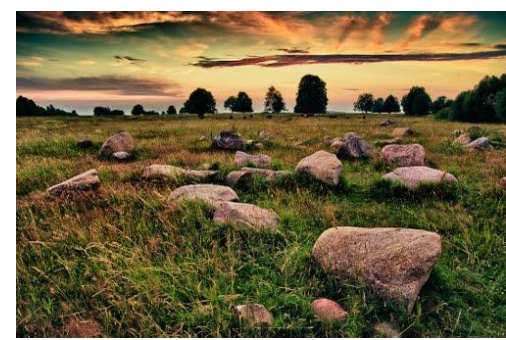

Рисунок 16 - Скалы Баханово, Рутка.

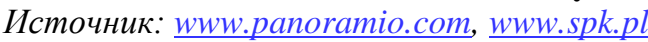

Августовский канал главным образом исполняет рекреационную функцию, обновления физических и психических сил. В Польше на трассе канала выступает один двухкамерный шлюз Панево, где разница уровня воды достигает 6,29 метров. Достопримечательность места Панево заняла пятнадцатое место в сфере здоровья и отдыха (33,68 \%) (рис. 17$)$. 


\begin{tabular}{|c|c|c|c|c|c|}
\hline Impact Factor: & $\begin{array}{l}\text { ISRA (India) } \\
\text { ISI (Dubai, UAE } \\
\text { GIF (Australia) } \\
\text { JIF }\end{array}$ & $\begin{array}{l}=1.344 \\
=0.829 \\
=0.356 \\
=1.500\end{array}$ & $\begin{array}{l}\text { SIS (USA) } \\
\text { PИHЦ (Russia } \\
\text { ESJI (KZ) } \\
\text { SJIF (Morocco }\end{array}$ & $\begin{array}{l}=0.912 \\
=0.179 \\
=1.042 \\
=2.031\end{array}$ & ICV (Poland) \\
\hline
\end{tabular}

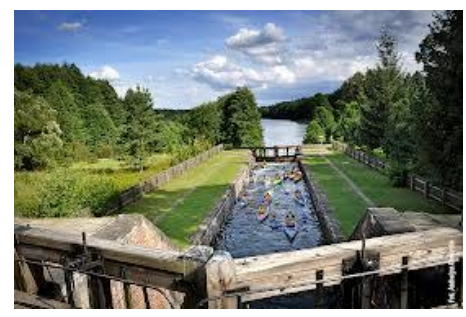

Рисунок 17 - Августовский канал - шлюз Панево.

Источник: www.polskiekrajobrazy.pl

Мосты в Станчиках достигающие 36 метров высоты и 200 метров длины одни из самых высоких этого типа построек в стране. Были местом прыжков на банджи-джампинг „тарзанка”. Теперь запрещено посещать часть мостов, так как техническое состояние объекта требует ремонта. Станчики заняли шестнадцатое место $(32,36 \%)$ (рис. 18$)$.

Источник: собственное

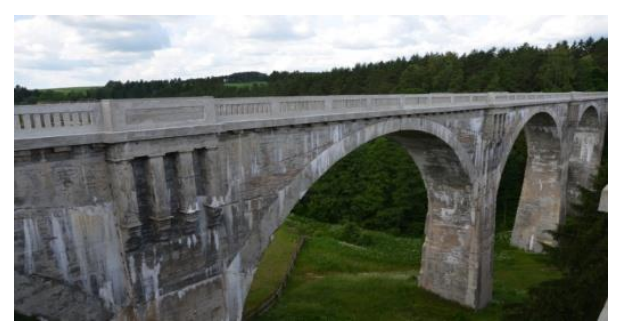

Рисунок 18 - Мосты Станчики.

Тисовая гора (семнадцатое место с результатом 32,34\%), высота 256 метров над уровнем моря лежит на территории Сувальскго Пейзажного Парка. На гору ведёт вытоптанная тропинка. Ближе вершины горы находятся перила вспомогательный вход. С пика простилается красивый вид на несколько окрестных озер. Теперь на горе происходят разнородные мероприятия и даже заключение браков (рис.19).

Источник: $\underline{\text { www.suwalki.info }}$

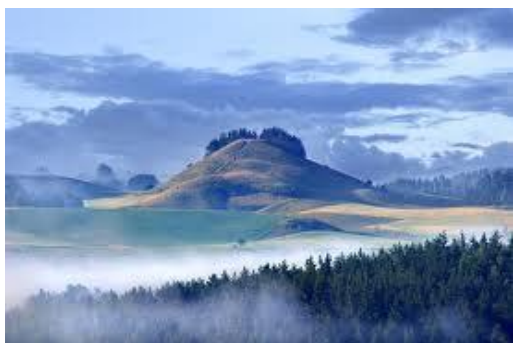

Рисунок 19 - Тисовая гора.
В оценке исследуемых зон отдыха последнее место с результатом $31,18 \%$ в сфере выполнения оздоровительных - для отдыха функции занял Вигерски Монастырь. Богатая история монастыря в большей сфере выполнение других чем здоровье и отдых функций туристики. На месте монастыря происходят летние пленары, концерты и ярмарки (рис.20). Результаты исследований выполнения оздоровительных - для отдыха функции показано на рис. 21. 


\begin{tabular}{|c|c|c|c|c|c|c|}
\hline Impact Factor: & $\begin{array}{l}\text { ISRA (India) } \\
\text { ISI (Dubai, UAE } \\
\text { GIF (Australia) } \\
\text { JIF }\end{array}$ & $\begin{array}{l}=1.344 \\
=0.829 \\
=0.356 \\
=1.500\end{array}$ & $\begin{array}{l}\text { SIS (USA) } \\
\text { PИНЦ (Russia) } \\
\text { ESJI (KZ) } \\
\text { SJIF (Morocco) }\end{array}$ & $\begin{array}{l}=0.912 \\
=0.179 \\
=1.042 \\
=2.031\end{array}$ & ICV (Poland) & $=6.630$ \\
\hline
\end{tabular}

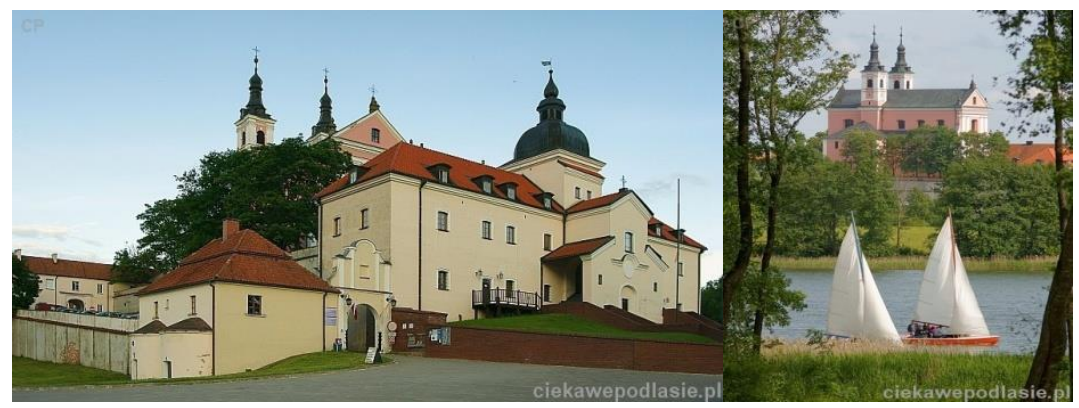

Рисунок 20 - Монастырский коллектив Камедулов в Виграх.

Источник: www.suwalszczyzna.com.pl

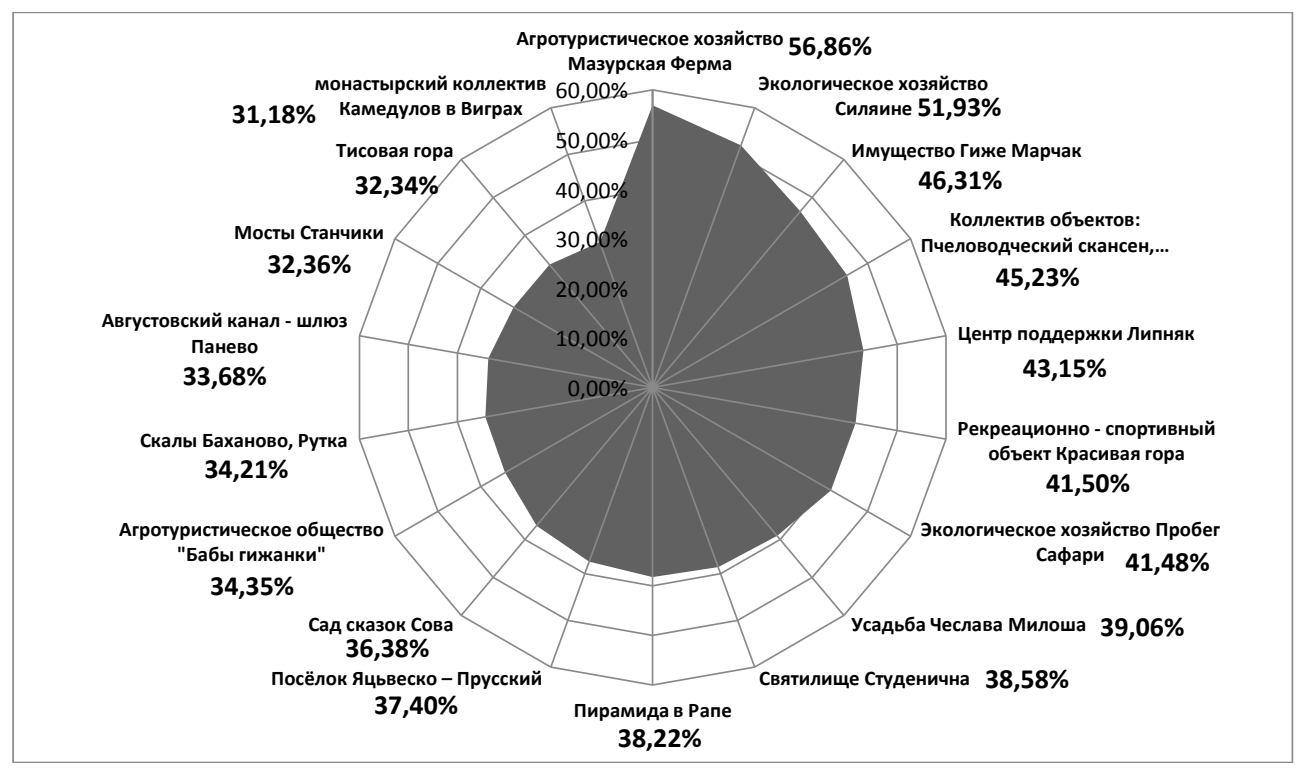

Рисунок 21 - Выполнение здровотно - курортных функции в туристических объектах северо восточной Польши в оценке исследуемых.

Источник: собственная обработка

\section{Выводы и предложения}

Исследования показали, что оздоровительная и функция отдыха наиболее эффективно реализованна в четырёх объектах: Мазурская ферма, Агротуристическое хозяйство Силяине, Имущество Гиже Марчак и коллектив объектов: Музей Пчеловодства, Железной дороги и Мастерская Скульптуры. Пробег Сафари и Поселение Яцьвеско - Прусское завоевали низшие оценки в сфере выполнения этих функций, что приводит к констатации: предположения не подтвердились полностью.

Предложения. Рекомендуемым была бы оценка отдельных мастерских и мероприятий организованных в описанных объектах. Оценки этого типа позволили бы сделать разделение взрослых мероприятий и школьных экскурсий по отношении к возрасту, мотивам, необходимостям и увлечениям.

\section{References:}

1. Gaworecki WW (1998) Turystyka. PWE, Warszawa 1998

2. Kaganek K, Stanuch H (2005) Modele regresyjne uprawiania turystyki aktywnej przez osoby niepełnosprawne wzrokowo I ruchowo, BIO-ALGORITHMS AND MED-SYSTEMS , JOURNAL EDITED BY MEDICAL COLLEGE - JAGIELLONIAN UNIVERSITY, 


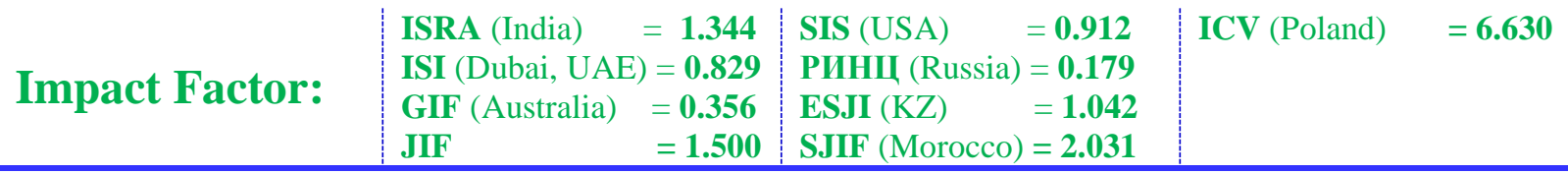

Vol. 1, No. 1/2, 2005, pp. 221-226. Available: http://bams.cm-uj.krakow.pl/wp/wpcontent/uploads/2013/12/bams-1-2.pdf (Accessed: 20.07.2015).

3. Kielan K, Pokora K (2006) Usługi turystyczne cz. I. [w:] Praca zbiorowa. Przygotowanie do działalności usługowej. Wybrane rodzaje usług. Liceum o profilu usługowo - gospodarczym. Podręcznik. Wyd. I. WSiP, Warszawa 2006. Available:

https://books.google.pl/books?id=nelw_FTUQB $0 \mathrm{C} \&$ printsec $=$ frontcover $\& \mathrm{hl}=\mathrm{pl} \&$ source $=\mathrm{gbs} \_\mathrm{g}$ e_summary_ $\mathrm{r} \& \mathrm{cad}=0 \# \mathrm{v}=$ onepage $\& \mathrm{q} \& \mathrm{f}=$ false (Accessed: 20.07.2015).

4. Kozłowska D, Ryszkowski W (2013) Funkcje etniczne i edukacji kulturalnej w ofercie wybranych miejsc turystycznych północno wschodniej Polski [w:] (red.) D. Kozłowska, K.L. Sobolewski, Ruch a zdrowie. Monografia pod patronatem International Association of Sport Kinetics. Dział Wydawnictw i Publikacji WSWFiT w Białymstoku, Białystok 2013, pp. 87-94.

Available: https://depot.ceon.pl/handle/123456789/6534 (Accessed: 20.07.2015).

5. Kozłowska D, Ryszkowski W (2013) Ocena realizacji funkcji turystycznych na przykładzie wybranych obiektów agroturystycznych [w:] (red.) I. I. Traciak Turystyka etnokulturowa $\mathrm{w}$ rejonie transgranicznym na obszarze województwa grodzieńskiego $\mathrm{i}$ w regionie suwalskim. Zbiór artykułów naukowych. Wydawnictwo TAA „JurSaPrynt”, maket, Grodno 2013, pp. 86-94.

6. Kozlovska D, Ryshkovski V (2014) Poznavatel'nye funktsii izbrannykh turisticheskikh ob"ektov severo - vostochnoy Pol'shi. Strategiya razvitiya industrii gostepriimstva i turizma: [Elektronnyy resurs]. - Materialy V Mezhdunarodnoy Internetkonferentsii 28 jan. - 25 apr. 2014. Pod obshchey red. d-ra tekhn. nauk, prof. E.N. Artemovoy, k.t.n., dots. N.V. Glebovoy. - Orel: Gosuniversitet - UNPK, 2014. pp. 322-327. Available: http://guunpk.ru/file/science/confs/turizm.pdf (Accessed: 20.07.2015).

7. Kozłowska D, Ryszkowski W (2014) URBANIZATsIONNAYa FUNKTsIYa IZBRANNYKh TURISTIChESKIKh OB""EKTOV SUVAL"ShchIZNY I GOLDAPSKOY ZEMLI [w:] Catching up new ideas: management, economics and law' 2014 : International Scientific Practical Conference, University of Applied Sciences, Kaunas, 17 April, 2014: collection of scientific articles, pp. 93-100.
8. Kozłowska D, Ryszkowski W (2013) Funkcje wychowawcze $w$ ofercie wybranych miejsc turystycznych północno - wschodniej Polski. Artykuł W języku polskim. [W:] „Zbilansowany rozwój regionów turystycznych: doświadczenia krajowe i światowe. Zbiór Materiałów Międzynarodowej Praktyczno Naukowej Konferencji (Lwów, 25-26 kwietnia 2013) Ministerstwo Oświaty i Nauki, Lwowski Instytut Ekonomiki i Turystyki, Departament Turystyki Międzynarodowej. Artykuł naukowy, wyd. TzOW „Liga -Pres” Ukraina-Lwów, 2013, pp. 168-171.

9. Łobożewicz T, Bieńczyk G (2001) Podstawy turystyki, wyd. Wyższa Szkoła Ekonomiczna, Warszawa 2001.

10. Napierała M, Żukow W, Muszkieta R (2009) Czynniki wpływające na rozwój turystyki. Funkcje i dysfunkcje turystyki [w:] Z. Kwaśniak (red.) Współczesne wyzwania turystyki i rekreacji dla zdrowia: zagadnienia pieleggnacyjne i fizjoterapeutyczne Current challenges of tourism and recreation to the health: issues in nursing and physiotherapeutic, wyd. Publishing House, Radomska Szkoła Wyższa, Radom 2009, pp. 87-112.

11.(2015) Available: www.atrakcjepodlasia.pl (Accessed: 20.07.2015).

12. (2015)

Available: www.marczaknoclegionline.net (Accessed: 20.07.2015)

13. (2015) Available: $\quad$ www.mazury.com (Accessed: 20.07.2015).

14. (2015) Available: www.mazury.info.com (Accessed: 20.07.2015).

15. (2015) Available: www.panoramio.com (Accessed: 20.07.2015).

16. (2015) Available: www.pl.123rf.com (Accessed: 20.07.2015).

17. (2015) Available: www.pogranicze.sejny.pl (Accessed: 20.07.2015).

18. (2015) Available: www.polskiekrajobrazy.pl (Accessed: 20.07.2015).

19. (2015) Available: www.silaine.mnt.pl (Accessed: 20.07.2015).

20. (2015) Available: www.spk.pl (Accessed: 20.07.2015).

21. (2015) Available: www.suwalki.info (Accessed: 20.07.2015).

22. (2015) Available: www.suwalszczyzna.com.pl (Accessed: 20.07.2015).

23. (2015) Available: www.zajazd-rudziewicz.pl (Accessed: 20.07.2015).

24. (2015) Available: www.za-mostkiem.pl (Accessed: 20.07.2015). 